\section{THREATENED BUtTERFLIES OF CENTRAL NePAL}

\author{
B. Khanal ${ }^{1}$, M.K. Chalise ${ }^{2} \&$ G.S. Solanki ${ }^{3}$
}

1 Natural History Museum, Manju Shree Bazaar, Swayambu, Kathamandu 44620, Nepal

${ }^{2}$ Central Department of Zoology, Tribhuvan University, Kirtipur, Kathmandu 44618, Nepal

${ }^{3}$ Department of Zoology, Mizoram University, Tanhril Campus, Aizawl, Mizoram 796004, India

${ }^{1}$ baya2000@live.com, ${ }^{2}$ mukesh57@hotmail.com, ${ }^{3}$ gssolanki02@yahoo.co.in (corresponding author)

In Nepal, the area above $3000 \mathrm{~m}$ is occupied mostly by palearctic butterflies while the temperate, subtropical and tropical species are sequentially distributed below this altitude. The temperate zone has many microhabitats to offer to different butterflies.

The central districts, namely, Kathmandu, Bhaktapur, and Lalitpur are dominated by evergreen broad-leaved mixed forests between 1800-2400 m. The evergreen Oak (Quercus) forest covers the area above $2000 \mathrm{~m}$ (DMP 1969). Conifers like Pinus roxburghii and Pinus wallichiana also occur in these districts. Besides Schima wallichii, Castanopsis indica and Alnus nepalensis can be observed in wet ravines. Other flora observed here are Ilex doniana, Zizyphus incurva, Leucodeptrum canum, Myrica esculenta, Myrsine semiserrata and Rhododendron arboreum.

The central region of Nepal was once forested (Upreti \& Ghimire 1982). These hills and valleys are now cultivated and very little forest is left (Chalise 2010). Some forested areas of this region are incorporated into the protected area network like the Langtang National Park and Nagarjun-Shivapuri National Park. The Langtang National Park lies at $32 \mathrm{~km}$ north of Kathmandu City while the latter is located close to this city with its northern boundary to the Nuwakot District. Teinopalpus imperialis, Papilio krishna, Diagora nicevillei, Troides aeacus etc. are the notable species found in the
Kathmandu Valley. The southern part of the valley, extending from Godavari $(1360 \mathrm{~m})$ to Phulchowki Mountain $(2734 m)$ is a species -rich area where more than 150 species of butterflies, mostly forest dwelling species, are found (Smith 1989). The recent loss of trees in

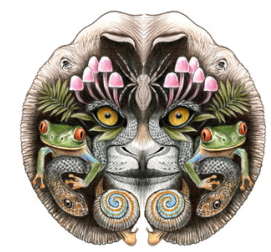

ISSN

Online 0974-7907 Print 0974-7893

\section{OPEN ACCESS} these forests has left the hills virtually bare except for a few areas between 2660-2715 m. These changes in the natural habitat have had a negative impact on the butterflies of the region. Therefore, an attempt has been made here to identify the threats imposed on some rare butterfly species of this region.

Material and Methods: The present study was carried out in the central part of Nepal which includes three districts-Kathmandu, Bhaktapur, and Lalitpur (Fig. $1)$. The base-line study consisted of direct observations made during 2004-2009 and comparison is made with the present study conducted during 2010-2011 in the three mentioned districts. A butterfly net was used for capturing insects. Data sheets and field guides as well as an altimeter and a diary were used in the field.

The peak diversity of butterflies was observed during May to August. Talbot $(1939,1947)$, Smith (1989) and Khanal \& Smith (1997) were consulted for identification. Capture and release method was adopted to identify species in the field. Habitat alteration was assessed minutely in relation to perceived threat factors. The species records mentioned in the National Red Data Book of Nepal (NRDB 1995) and the field data resulted from the study made in the central districts in 2004 to 2011, are considered for the current status of the species.

Results: The interesting findings of this study are mentioned in Table 1. Four species of butterflies were found at low density and therefore, are considered at high risk. These species are restricted to narrow

DOI: http://dx.doi.org/10.11609/JoTT.o2825.4612-5 | ZooBank: urn:Isid:zoobank.org:pub:100E053D-1C22-4CDD-8E1D-AB26DD89BA6A

Manuscript details: Ms \# 02825 | Received 08 June 2011 | Final received 20 June 2013 | Finally accepted 02 July 2013

Citation: Khanal, B., M.K. Chalise \& G.S. Solanki (2013). Threatened butterflies of central Nepal. Journal of Threatened Taxa 5(11): 4612-4615; http://dx.doi. org/10.11609/JoTT.02825.4612-5

Copyright: @ Khanal et al. 2013. Creative Commons Attribution 3.0 Unported License. JoTT allows unrestricted use of this article in any medium, reproduction and distribution by providing adequate credit to the authors and the source of publication.

Funding: None.

Competing Interest: None. 


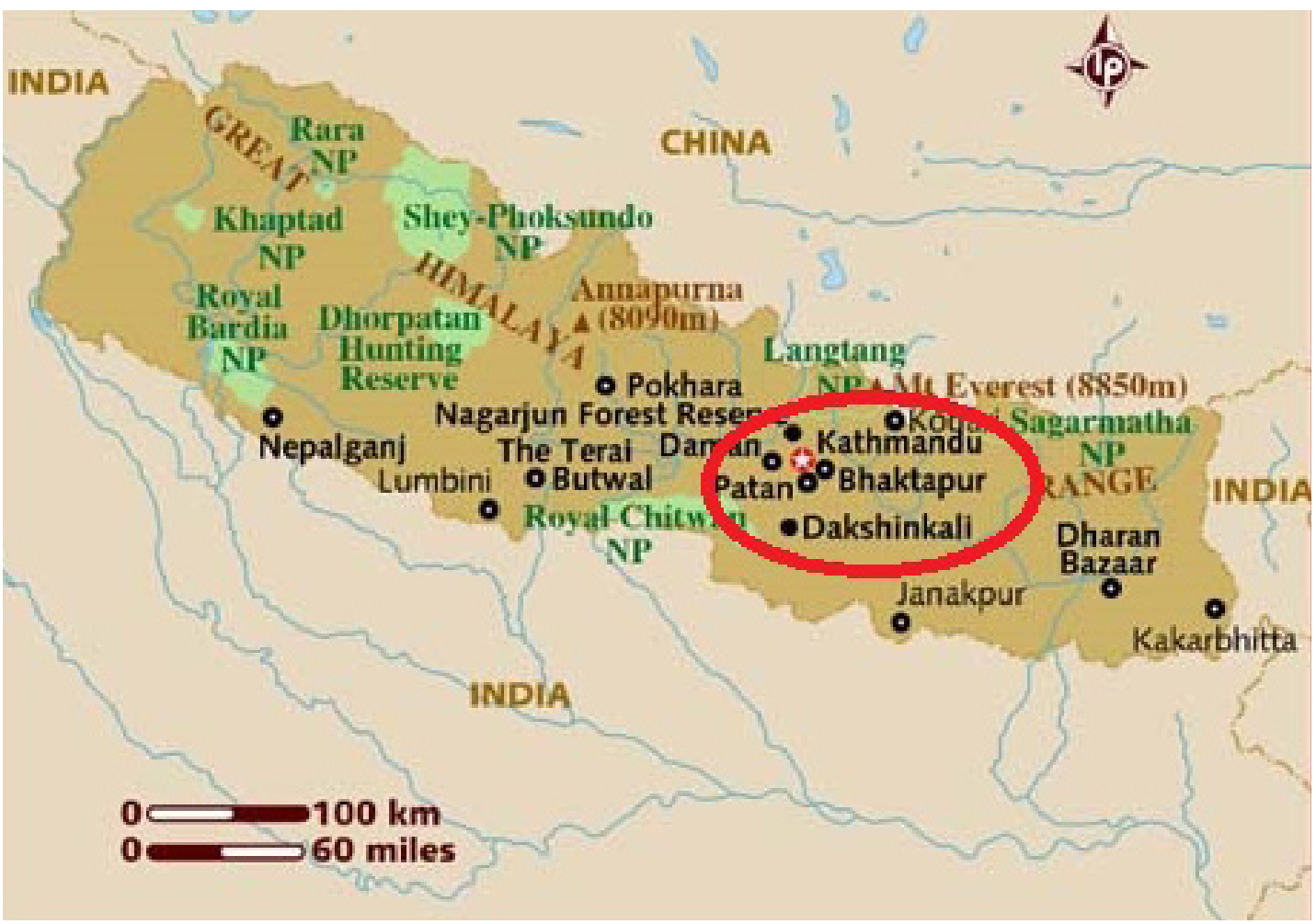

Figure 1. Study Areas

distributional ranges in all the three districts. These species are Teinopalpus imperialis, Papilio krishna, Meandrusa lachinus, and Euripus consimilis. Other species surveyed in this study are under declining state as shown by the field studies conducted in 2004-2011.

Discussion and Conclusion: The human population in the central part of Nepal is rising rapidly (CBS 2003). Tourist inflow is also comparatively high in this region. Some areas of the central districts are included in the protected area network, except the Godavari and Phulchoki forests where a rich diversity of butterflies, with several rare and endemic species and subspecies are found. Study based on field surveys from 2004 to 2011 has indicated that 19 species are now under very low density in their known habitats. Shrinkage of habitats due to construction of roads and establishment of quarry industry are, therefore, imposing severe impacts on the species like Chrysozephyrus disparatus interpositas, Thermozephyrus ataxus, Maneca bhotea, Pamela dudgeoni dudgeoni Celastrina hersilia vipia, Neptis manasa Neptis nycteus, Phaedyma aspasia kathmandia, Euthalia dudu Diagora nicevillei, Lethe latiaris hige, and Satarupa zulla. None of these species have been reported in other parts of the country except the central districts considered for this study.
Teinopalpus imperialis, Meandrusa lachinus, Papilio krishna, and Maneca bhotea dwell in forests, being usually found on mountain tops where vegetation like Quercus semicarpifolia, Michelia sp., Rhododendron arboreum and Daphne bholua are found. Meandrusa lachinus has a very narrow range along the Himalaya from Uttarakhand to Arunachal Pradesh and the mountains of Laos and China.

The probable factors imposing severe impacts on the above mentioned species are:

(1) Forest clearing for governmental activities and tourism, which has a negative impact on populations of these butterflies in Kathmandu Valley.

(2) Daphne bholua, a host plant of Teinopalpus imperialis, is used in the paper industry and has been extensively harvested in these areas. These factors have caused the butterfly species mentioned above to be included in the "endangered" category (Smith 1989).

Pamela dudgeoni, Neptis manasa, N. nycteus, Phaedyma aspasia, Diagora persimilis, D. nicevillii are restricted to forest habitats close to streams, where vegetation like Quercus semecarpifolia, Alnus nepalensis, Celtis tetranda and Schima wallichii are found.

(3) Streams in Godavari forest have now dried up presumably due to the impact of marble quarrying, 
Table 1. Threatened butterfly species and altitudinal distribution across the study area

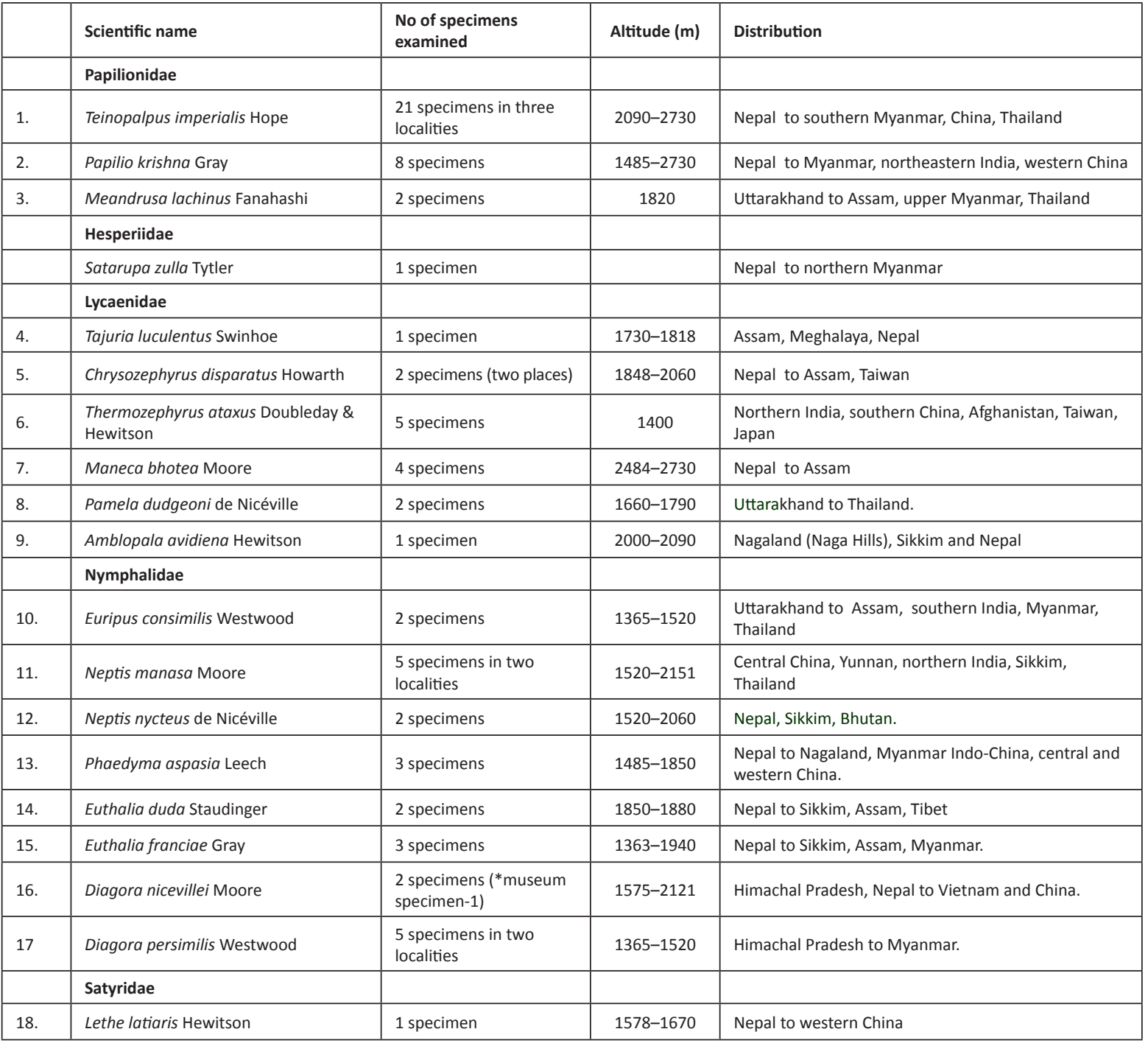

*Natural History Museum in Kathmandu

which has been going on in the area for the last several years.

(4) Celtis tetranda, the host plant of Diagora persimilis is lopped for fodder.

(5) Diagora nicevillei, an endangered nymphalid, is probably one of the rarest butterflies in the world (Smith 1990). Furthermore, the only known Himalayan population is confined to a small pocket in Godavari forest and the area has now been reduced due to stone quarrying and deforestation.

(6) Other threats perceived elsewhere for $D$. nicevillei include grazing, mining, unsustainable uses of biological resources, urbanization, tourism and illegal trade (Khanna \& Kumar 2001). This species is given protection under Schedule I (Part - IV) of the Indian Wildlife (Protection)
Act, 1972 (Singh \& Singh 2002). In the National Red Data Book of Nepal it has been included in the endangered category (NRDB 1995). This species has five subspecies known so far which includes D.n. nicevillei Moore from Chamba to western Nepal; D.n. nigra Morishita from the Kathmandu Valley; jermyni Druce from the Tons Valley, India; ouvrardi Watkins from northwestern Yunnan, southeastern Tibet, China and magna Omoto \& Funahashi from Vietnam.

(7) Tajuria luculentus, Celastrina hersilia and Euthalia duda are found from 1730-1880 $\mathrm{m}$ in mixed forest of Alnus nepalensis and Quercus semicarpifolia (DMP 1969). In Nagarjun, a large forest area has been cleared to build monasteries and roads.

(8) The marble mining at Godavari has destroyed a 
large portion of the habitat of many rare and endangered species including Teinopalpus imperialis, Papilio krishna, Phaedyma aspasia and Euthalia duda. Chalise (1978) in his study at Godavari found that nine species of nymphalids were becoming increasingly rare.

(10) The habitat of Amblopala avidiena in Nagarjun forest is threatened mainly due to the broadening of roads and building of monasteries.

(11) Lethe latiaris, which inhabits shady QuercusAlnus forest at $1670 \mathrm{~m}$ is impacted mostly due to road construction, picnickers and herb collectors. Godavari forest is notorious for these ecological malpractices.

Euripus consimilis occurs sparingly at 1370-1400 m; its host plant, Trema orientalis, is an uncommon tree at low elevation and it may be commoner in the belt below 1000 m elevation. The population of Satarupa zulla, which also occurs at the same elevation as Euripus consimilis but in Alnus-Quercus forest which is also declining due to increasing anthropogenic activities in this part. The status of many species is changing mainly due to habitat degradation. Only two species, Troides aeacus and Troides helena have been listed in CITES Appendix II (Khanal et al. 2010). Nepal Red Data Book (1995) incorporated 142 species of butterflies under different threat categories.

The continued habitat degradation and pressure on natural resources is adversely affecting butterfly populations outside the protected area network. There is a need for discovering, assessing and taking steps for long term conservation initiatives for endangered butterfly taxa, especially involving the local community and government.

\section{REFERENCES}

CBS (2003). Population Monograph of Nepal. Central Bureau of Statistic, Kathmandu, Nepal, 412+xxivpp.

Chalise, P. (2010). Biodiversity of butterflies in Badikhel VDC, Lalitpur, Nepal. MSc Dissertation. Submitted to the Central Department of Zoology (Entomology), Tribhuvan University, Kathmandu (unpublished), 58pp.

Chalise, M.K. (1978). Collection of butterflies around Kathmandu Valley. A project work of BSc, submitted to the Tri-Chandra College, Kathmandu Nepal (unpublished): 21+5pp.

DMP (1969). Flora of Phulchoki and Godavari. Department of Medicinal Plants, Nepal Government, Kathmandu, Nepal 144pp.

Khanal, B., M.K. Chalise \& G.S. Solanki (2010). Study on the biodiversity of butterflies and their current status in Central Nepal. Abstract, $3^{\text {rd }}$ Asian Lepidoptera Conservation Symposium and Training Programme, Coimbatore, South India, 16pp.

Khanal, B. \& C.Smith (1997). Butterflies of Kathmandu Valley. Tec Press Books, Bangkok, Thailand, 6-10pp.

Khanna, V. \& A. Kumar (2001). Mountains: Western Himalaya, pp.3540. In: Alfred, J.R.B., A.K. Das \& A.K. Sanyal (eds.). Ecosystems of India. ENVIS-Zoological Survey of India, Kolkata India.

NRDB (1995). Red Data Book of the Fauna of Nepal. Biodiversity Profile Project Technical Publication No.4, Department of National Parks and Wildlife Conservation, Nepal Government, Babar Mahal Kathmandu, Nepal, 150pp.

Singh, N.P. \& D.K. Singh (eds.) (2002). Protected area network, 5: 2341-2412 In: Floristic Diversity and Conservation in India. Botanical Survey of India, Dehra Dun.

Smith, C. (1990). Beautiful Butterflies. A. Colourful Introduction to Nepal's Most Beautiful Insects. Tribhuvan University, Kathmandu, Nepal. Know Nepal series No. 3: 33pp+229 illustrations.

Talbot, G. (1939). Fauna of British India - Volume I. Taylor and Francis, London, 54-304pp.

Talbot, G. (1947). Fauna of British India - Volume II. Taylor and Francis, London, 166-233pp.

Upreti, B.K. \& G.P.S. Ghimire (1982). Numerical analysis of forest flora and its relation with soil characteristics in Phulchoki Mountain, Kathmandu. Journal of Natural History Museum 6(1-4): 19-38. 